\title{
Pendugaan Awal Patahan di Pulau Jawa Menggunakan Anomali Gravitasi dan Riwayat Kegempaan
}

\author{
Preliminary Fault Prediction in Java Island Using Gravity Anomaly and \\ Earthquakes History
}

\author{
Theo Alvin Ryanto*, Hadi Suntoko, Abimanyu Bondan Wicaksono Setiaji \\ Pusat Kajian Sistem Energi Nuklir-BATAN, \\ Jalan Kuningan Barat, Mampang Prapatan, Jakarta, Indonesia 12710 \\ *E-mail: theo.alvin@batan.go.id
}

Naskah diterima: 24 Juni 2019, direvisi: 9 Juli 2019, disetujui: 10 Juli 2019

DOI: $10.17146 /$ eksplorium.2019.40.1.5470

\begin{abstract}
ABSTRAK
Informasi mengenai keberadaan patahan sangat diperlukan dalam perencanaan pembangunan industri, terutama pada perencanaan tapak Pembangkit Listrik Tenaga Nuklir (PLTN). Penelitian ini bertujuan untuk membuat dugaan awal keberadaan patahan di Pulau Jawa dengan menggunakan data anomali gravitasi udara bebas dan riwayat kegempaan. Metodologi yang digunakan adalah dengan memisahkan data anomali gravitasi regional dan residual. Data tersebut kemudian dianalisis dengan cara menarik garis kemenerusan kontras nilai anomali gravitasi regional dan residual yang memiliki kecocokan dengan kemenerusan sebaran titik episentrum gempa. Berdasarkan hasil analisis, beberapa kelurusan di Pulau Jawa diperkirakan sebagai patahan yang berarah relatif utara-selatan dan barat-timur.
\end{abstract}

Kata kunci: patahan, anomali gravitasi, gempa

\begin{abstract}
Information related to the fault existences is needed for industrial development planning, mainly on the Nuclear Power Plant (NPP) site planning. This study is aimed to build preliminary prediction on faults existence in Java Island by using free-air gravity and earthquakes history data. The methodologies are separating regional with residual gravity anomalies and then analyzing them by correlating the continuity of their contrast values which have similarities with the distribution of earthquakes epicenters point. Based on the analysis, some lineaments in Java Island are predicted as faults which relatively directing to north-south and west-east.
\end{abstract}

Keywords: fault, gravity anomaly, earthquake

\section{PENDAHULUAN}

Pulau Jawa adalah pulau terpadat di Indonesia dan memiliki perkembangan industri serta penduduk yang sangat pesat. Hingga saat ini, Pulau Jawa merupakan pusat perkembangan ekonomi dan industri di Indonesia. Hal ini menyebabkan Pulau Jawa memiliki kebutuhan energi yang sangat besar dan akan terus bertambah seiring waktu. Pada tahun 2017 terdapat 320 pembangkit listrik aktif di Pulau Jawa yang terdiri dari pembangkit listrik tenaga uap, air, gas, panas bumi, diesel, serta gas-uap dengan total kapasitas daya 26014,85 MW. Selama lima tahun, sejak tahun 2012 hingga 2017, telah dibangun 38 pembangkit listrik dan hingga saat ini masih terus bertambah untuk memenuhi kebutuhan listrik rumah tangga dan industri [1]. Pembangkit Listrik Tenaga Nuklir (PLTN) merupakan salah satu alternatif pembangkit listrik yang memiliki kapasitas daya yang relatif besar sehingga dapat digunakan untuk menjamin pasokan energi listrik di Pulau Jawa. 
Standar keamanan untuk lokasi tapak PLTN telah diatur secara internasional oleh Badan Atom Internasional (International Atomic Energy Agency/IAEA) dan secara nasional oleh Badan Pengawas Tenaga Nuklir (BAPETEN). Menurut Perka BAPETEN No 8 Tahun 2013 tentang kegempaan, lokasi tapak PLTN tidak dapat berada pada area dengan radius $5 \mathrm{~km}$ dari patahan kapabel [2]. Oleh karena itu, studi mengenai patahan merupakan salah satu hal yang harus dilakukan untuk mendapatkan lokasi tapak potensial PLTN.

Secara geologi, Pulau Jawa memiliki struktur yang kompleks. Subduksi antara Lempeng Indo-Australia yang menunjam Lempeng Eurasia terjadi di sepanjang Pulau Jawa. Aktivitas tektonik ini menyebabkan terbentuknya berbagai struktur geologi di Pulau Jawa, salah satunya adalah patahan/sesar. Ada beberapa patahan aktif di Pulau Jawa, yaitu Patahan Cimandiri, Patahan Lembang, Patahan Baribis, Sesar Opak, dan sebagainya [3]. Keberadaan patahan tersebut dapat memicu terjadinya gempa bumi di Pulau Jawa.

Gempa dapat disebabkan oleh beberapa sumber, yaitu sumber gempa subduksi yang diakibatkan oleh kontak antar lempeng dan sumber gempa patahan yang diidentifikasi berdasarkan geometri patahan [4]. Kedua jenis sumber gempa tersebut disebabkan oleh adanya aktivitas tektonik. Tekanan yang disebabkan oleh aktivitas tektonik akan mempengaruhi batuan yang berada di sekitar zona tektonik sehingga energinya tersimpan di dalam batuan. Tekanan tersebut dapat menyebabkan batuan memiliki zona lemah, seperti kekar atau rekahan. Ketika energi yang tersimpan di dalam batuan telah mencapai titik kritis, maka terjadi pelepasan energi sehingga rekahan tersebut bergerak. Pergerakan rekahan, disebut juga sebagai patahan/sesar, kemudian menjadi sumber gempa bumi.

Sejarah rekaman gempa dapat digunakan untuk memperkirakan arah patahan berdasarkan pola-pola kemenerusan sebaran titik pusat/episentrum gempa. Titik episentrum gempa pada zona tektonik sangat banyak dan berada di bawah permukaan sehingga sulit untuk menentukan kemenerusan patahan. Oleh karena itu, dibutuhkan data lain sebagai acuan untuk menarik garis perkiraan kemenerusan patahan.

Metode gravitasi merupakan salah satu metode geofisika yang dapat digunakan sebagai acuan penarikan garis patahan. Analisis pendugaan lokasi patahan dapat dilakukan dengan menggunakan kombinasi antara nilai anomali gravitasi dengan data kegempaan [5]. Metode gravitasi dapat mendeteksi variasi nilai percepatan gravitasi di bawah permukaan. Variasi percepatan gravitasi ini disebabkan oleh adanya perbedaan medan gravitasi akibat variasi densitas batuan di kerak bumi. Variasi nilai densitas batuan di bawah permukaan dipengaruhi oleh adanya variasi litologi batuan secara lateral yang dapat disebabkan oleh berbagai hal, seperti adanya perbedaan lapisan batuan, struktur geologi patahan, lipatan, dan sebagainya [6]. Salah satu kelebihan yang dimiliki oleh metode gravitasi adalah mampu mendeteksi keberadaan struktur geologi di bawah permukaan meskipun tidak terdapat indikasi adanya struktur geologi di permukaan. Adanya patahan akan tetap mempengaruhi variasi nilai densitas batuan terlepas dari ada atau tidaknya kenampakan patahan tersebut di permukaan. Keberadaan patahan dapat diindikasikan dengan adanya kemenerusan kontras nilai anomali percepatan gravitasi. 
Tujuan dari penelitian ini adalah untuk memetakan perkiraan keberadaan patahan di Pulau Jawa dengan menggunakan data anomali gravitasi udara bebas dan data kegempaan. Informasi mengenai patahan ini dapat menjadi salah satu studi awal untuk menentukan tapak-tapak potensial untuk PLTN di Pulau Jawa.

\section{METODOLOGI}

\section{Konsep Dasar Metode Gravitasi}

Metode gravitasi didasari oleh prinsip fisika menurut hukum Newton mengenai interaksi antara dua partikel dengan massa yang terpisah sejauh jarak tertentu. Hukum gravitasi Newton menyatakan apabila $\vec{F}$ adalah nilai gaya gravitasi; $G$ merupakan konstanta gravitasi universal $\left(6,67 \times 10^{-11} \mathrm{~m}^{3}\right.$ $\left.\mathrm{kg}^{-1} \mathrm{~s}^{-2}\right) ; m_{1}$ dan $m_{2}$ adalah massa; $r$ adalah jarak; dan $\hat{r}$ adalah unit vektor pada arah koordinat $r$ yang berasal dari pusat massa, maka nilai gaya gravitasi dapat dinyatakan menurut persamaan berikut [7]:

$$
\vec{F}=-G \frac{m_{1} m_{2}}{r^{2}} \hat{r}
$$

Nilai percepatan gravitasi pada setiap titik pengukuran gravitasi setidaknya dipengaruhi oleh lima faktor [6, 7], yaitu:

1. Posisi pengukuran pada garis lintang

2. Ketinggian titik ukur

3. Posisi bulan dan matahari

4. Medan topografi di sekitar titik pengukuran

5. Anomali batuan di bawah permukaan

Anomali gravitasi udara bebas adalah nilai percepatan gravitasi yang sudah tidak dipengaruhi oleh posisi garis lintang, ketinggian titik ukur, serta posisi bulan dan matahari. Anomali gravitasi udara bebas didapatkan dengan cara mengoreksi nilai gravitasi observasi dengan anomali bouguer, yaitu massa gravitasi yang terbentuk di atas garis datum. Berikut adalah rumus yang menunjukkan hubungan antara nilai gravitasi observasi dengan gravitasi udara bebas:

$$
g_{f a}=g_{o b s}-g_{N}-F A C
$$

$g_{f a}$ adalah nilai anomali gravitasi udara bebas; $g_{o b s}$ adalah nilai percepatan gravitasi yang diukur di lapangan; $g_{N}$ adalah nilai gravitasi teoritis; FAC adalah nilai koreksi udara bebas untuk menghilangkan pengaruh ketinggian titik ukur.

\section{Metode Upward Continuation}

Metode Upward Continuation adalah salah satu metode analitik yang digunakan untuk memisahkan anomali regional dan residual pada nilai percepatan gravitasi. Pada penelitian ini, metode Upward Continuation digunakan untuk pemisahan anomali pada anomali gravitasi udara bebas. Metode ini mentransformasi medan potensial yang diukur pada suatu permukaan sehingga medan potensial di tempat lain berada di atas permukaan pengukuran dan cenderung menonjolkan anomali yang berpengaruh secara regional atau luas dengan menghilangkan anomali yang bersifat lokal. Perhitungan nilai medan potensial di setiap titik observasi pada bidang hasil kontinuasi (z) dapat dilakukan dengan menggunakan persamaan berikut [8]:

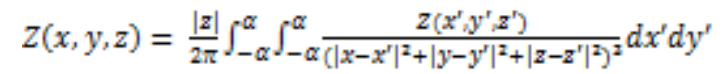

Anomali residual diperoleh dengan menghitung selisih nilai anomali gravitasi terhadap anomali regional $[6,9]$.

Data yang ditampilkan oleh anomali regional cenderung berupa anomali dengan frekuensi rendah dan memiliki pengaruh skala besar dalam area penelitian (Gambar 1). Anomali residual berisi data dengan frekuensi 
tinggi yang berpengaruh pada area yang relatif lebih sempit dan terbatas [6].

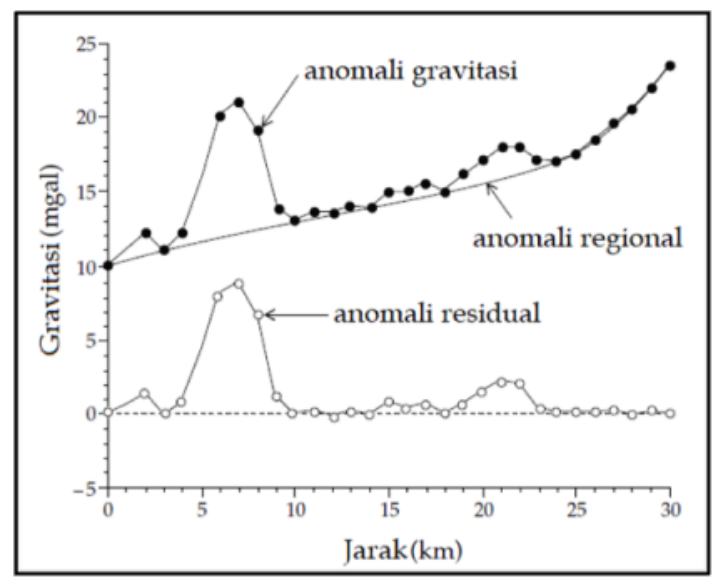

Gambar 1. Pemisahan anomali regional residual [6].

\section{Analisis Patahan pada Metode Gravitasi}

Keberadaan patahan akan menyebabkan adanya perubahan densitas secara lateral akibat perubahan posisi massa batuan di bawah permukaan. Nilai anomali gravitasi pada patahan akan bertambah secara progresif hingga tingkat maksimum pada sisi patahan yang terangkat. Hal ini disebabkan oleh material densitas tinggi yang mengalami pengangkatan oleh aktivitas patahan dan menyebabkan adanya kontras densitas secara horizontal. Posisi patahan secara umum berada diantara pertengahan nilai gravitasi minimum dan maksimum (Gambar 2) [10].

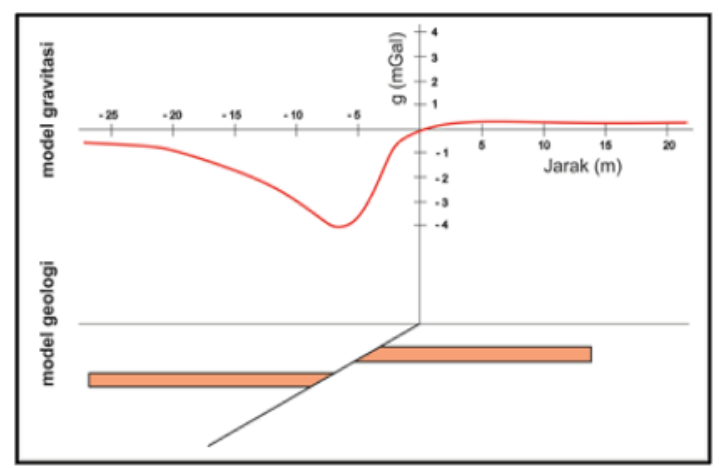

Gambar 2. Model patahan pada anomali gravitasi [10].

Terdapat tiga jenis patahan berdasarkan pergerakan hanging wall dan foot wall, yaitu patahan turun, naik, dan mendatar (Gambar 3) [11]. Metode gravitasi dapat mendeteksi patahan turun dan naik, akan tetapi patahan mendatar tidak dapat teridentifikasi. Hal ini disebabkan pada patahan mendatar, umumnya tidak terjadi perubahan densitas secara vertikal.

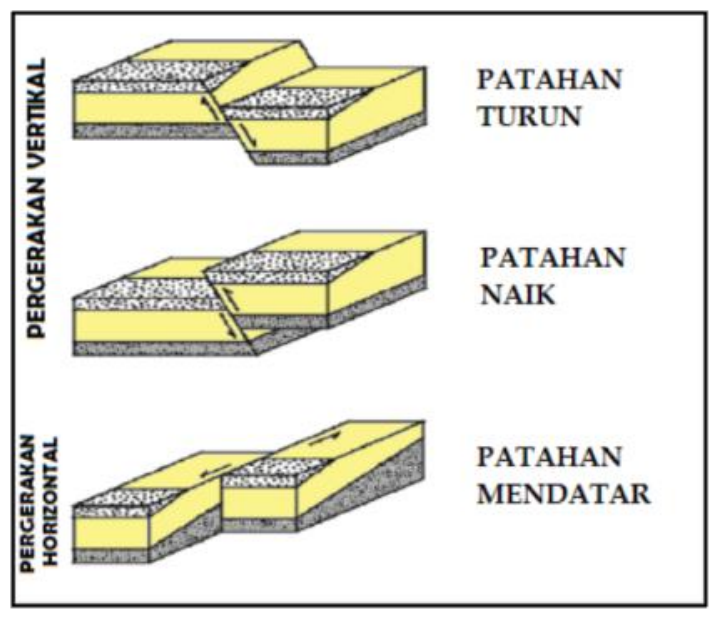

Gambar 3. Jenis Patahan [11].

Hasil analisis variasi densitas batuan dapat digunakan untuk memetakan patahan yang berpotensi aktif. Akan tetapi, hasil analisis tidak dapat menentukan keberadaan patahan secara langsung. Analisis variasi densitas batuan hanya dapat menunjukkan indikasi keberadaan patahan, terlepas dari patahan tersebut aktif atau tidak. Oleh karena itu, data lain seperti data kegempaan dan GPS geodetik diperlukan untuk menemukan indikasi keberadaan patahan aktif.

\section{Diagram Alir Penelitian}

Penelitian ini dilakukan dengan menggunakan data gempa dan gravitasi sekunder. Data gravitasi udara bebas didapatkan dari http://topex.ucsd.edu/cgibin/get data.cgi. Anomali gravitasi udara bebas dapat digunakan untuk analisis pada area regional dengan baik [12] sehingga cocok digunakan untuk penelitian secara regional di Pulau Jawa. Data gempa mulai 
dari 1 April 1972 hingga 1 April 2019 didapatkan dari katalog gempa yang diunduh di laman USGS (http://earthquake.usgs.gov) dengan kedalaman sumber gempa $<50 \mathrm{Km}$.

Pengolahan data dilakukan dengan perangkat lunak ArcGIS. Sebelum dilakukan analisis gabungan antara data gravitasi dan kegempaan, penapisan data pada anomali gravitasi udara bebas dilakukan untuk memisahkan anomali regional dan residual terlebih dahulu. Metode penapisan data yang digunakan untuk memisahkan anomali regional dan residual adalah metode Upward Continuation. Setelah anomali regional dan residual pada data anomali gravitasi udara bebas dipisahkan, dilakukan penarikan perkiraan patahan dengan cara menarik garis kemenerusan kontras nilai pada anomali gravitasi regional dan residual yang memiliki kecocokan dengan kemenerusan sebaran titik episentrum gempa [5, 12, 13]. Diagram alir untuk analisis pendugaan awal patahan ditunjukkan pada Gambar 4.

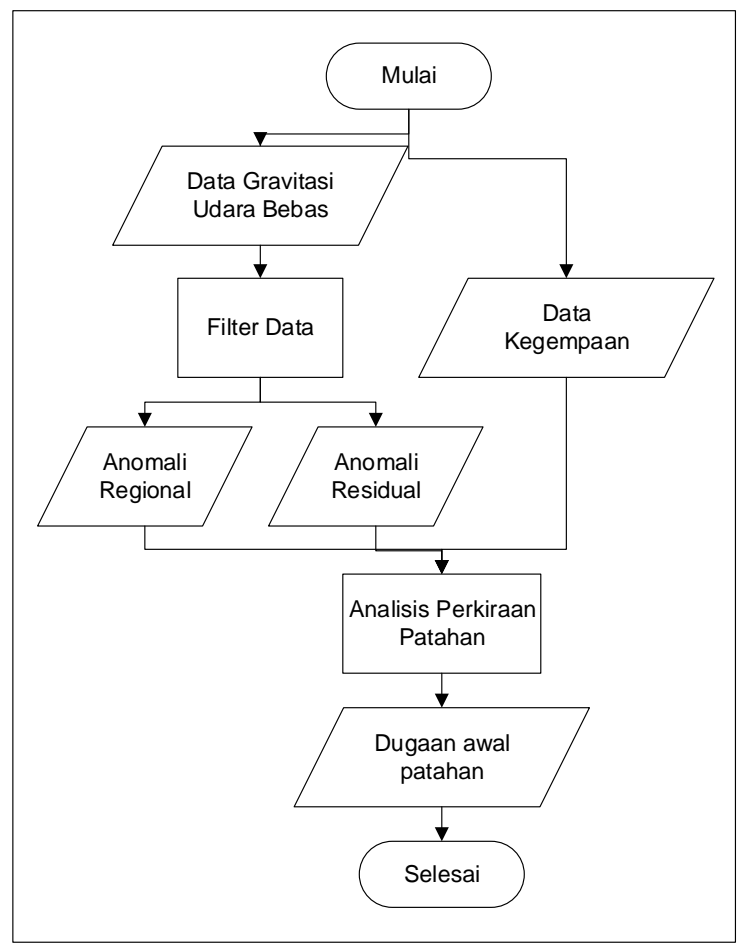

Gambar 4. Diagram alir penelitian.

\section{HASIL DAN PEMBAHASAN}

Target patahan yang akan diperkirakan adalah patahan yang berada pada kedalaman relatif dangkal sehingga data gempa yang digunakan dalam penelitian ini adalah gempa dengan kedalaman dangkal $(<50 \mathrm{~km})$. Berdasarkan data yang didapatkan, USGS telah mencatat ada 1490 event gempa di sekitar Pulau Jawa sejak 1 April 1972 hingga 1 April 2019 dan ditampilkan pada Gambar 5. Titik pusat gempa atau episentrum gempa tersebar di sepanjang Pulau Jawa dan terkonsentrasi di laut selatan Pulau Jawa. Hal ini dikarenakan bagian selatan Pulau Jawa merupakan zona subduksi antara lempeng Indo-Australia dengan lempeng Eurasia.

Berdasarkan sumbernya, gempa dapat disebabkan oleh tumbukan lempeng pada zona batas tektonik atau pergerakan patahan pada batuan. Sesuai dengan tujuan dari penelitian ini, titik gempa yang akan dianalisis lebih lanjut adalah titik gempa yang diindikasikan terjadi akibat pergerakan patahan di daratan pulau.

Data anomali gravitasi yang didapatkan dari TOPEX dipetakan dengan ARCGIS dan ditampilkan pada Gambar 6. Penelitian ini menggunakan data anomali gravitasi udara bebas tanpa dilakukan pengolahan lebih lanjut. Secara keseluruhan, terlihat bagian selatan Pulau Jawa memiliki nilai anomali gravitasi yang relatif lebih tinggi (55-362 mGal) sedangkan bagian utara memiliki nilai anomali gravitasi yang relatif rendah $(-174$ $50 \mathrm{mGal}$ ). Hal ini bisa disebabkan oleh faktor jenis batuan yang menyusun daerah tersebut. Bagian selatan Pulau Jawa cenderung didominasi oleh batuan gunung api dan batugamping yang memiliki densitas relatif tinggi sedangkan daerah utara Pulau Jawa cenderung didominasi oleh batuan atau endapan dengan densitas rendah. Selain itu, terdapat kemungkinan adanya patahan mayor 
yang melintang sepanjang Pulau Jawa. Hal ini diindikasikan dengan kontras nilai anomali gravitasi yang melintang relatif timur-barat sepanjang pulau.

Proses penapisan data dilakukan pada data anomali gravitasi untuk memisahkan anomali regional dan anomali residual. Hasil dari pemisahan anomali hanya dapat digunakan untuk interpretasi secara kualitatif karena kalkulasi matematis pada proses ini tidak menunjukkan nilai residual sesungguhnya dari batuan [14]. Anomali gravitasi regional ditampilkan pada Gambar 7. Anomali gravitasi regional adalah hasil dari pemisahan anomali yang dilakukan dengan metode upward continuation dan menonjolkan anomali gravitasi dengan pengaruh area yang luas dan dominan. Identifikasi perkiraan patahan pada penelitian ini dilakukan dengan menarik garis kemenerusan kontras nilai tinggi ke rendah pada anomali gravitasi yang memiliki kecocokan dengan kemenerusan sebaran titik episentrum gempa.

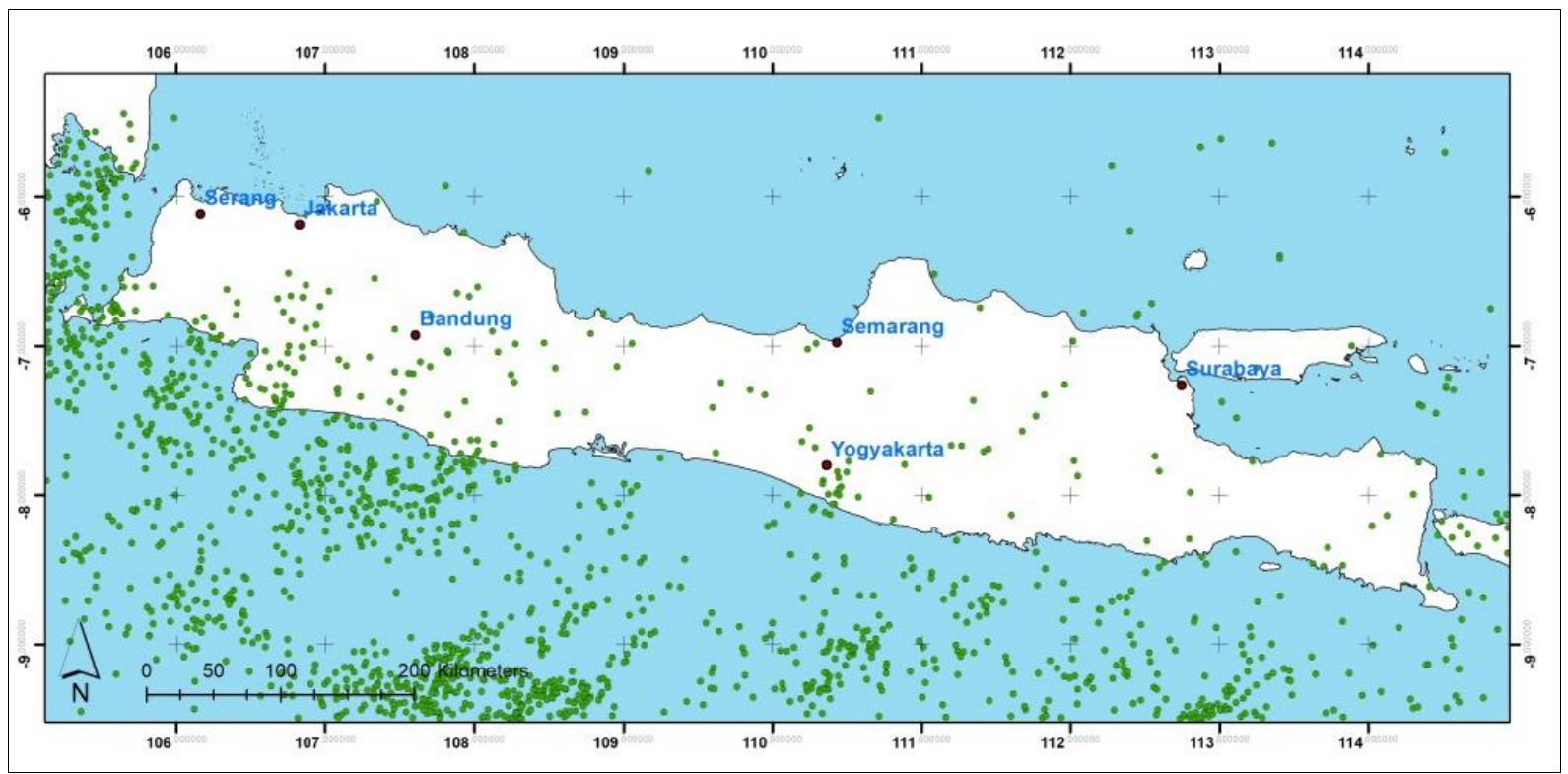

Gambar 5. Sebaran data gempa USGS.

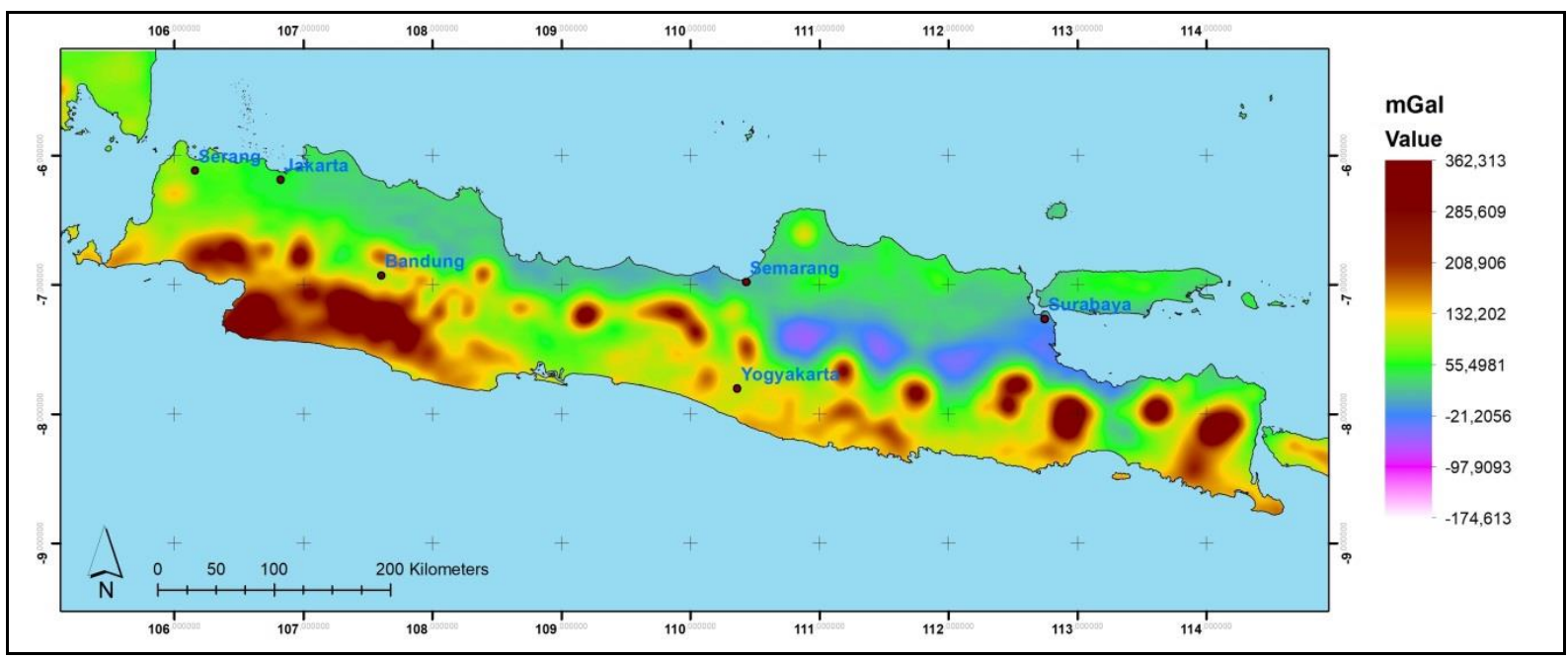

Gambar 6. Anomali gravitasi udara bebas di Pulau Jawa. 


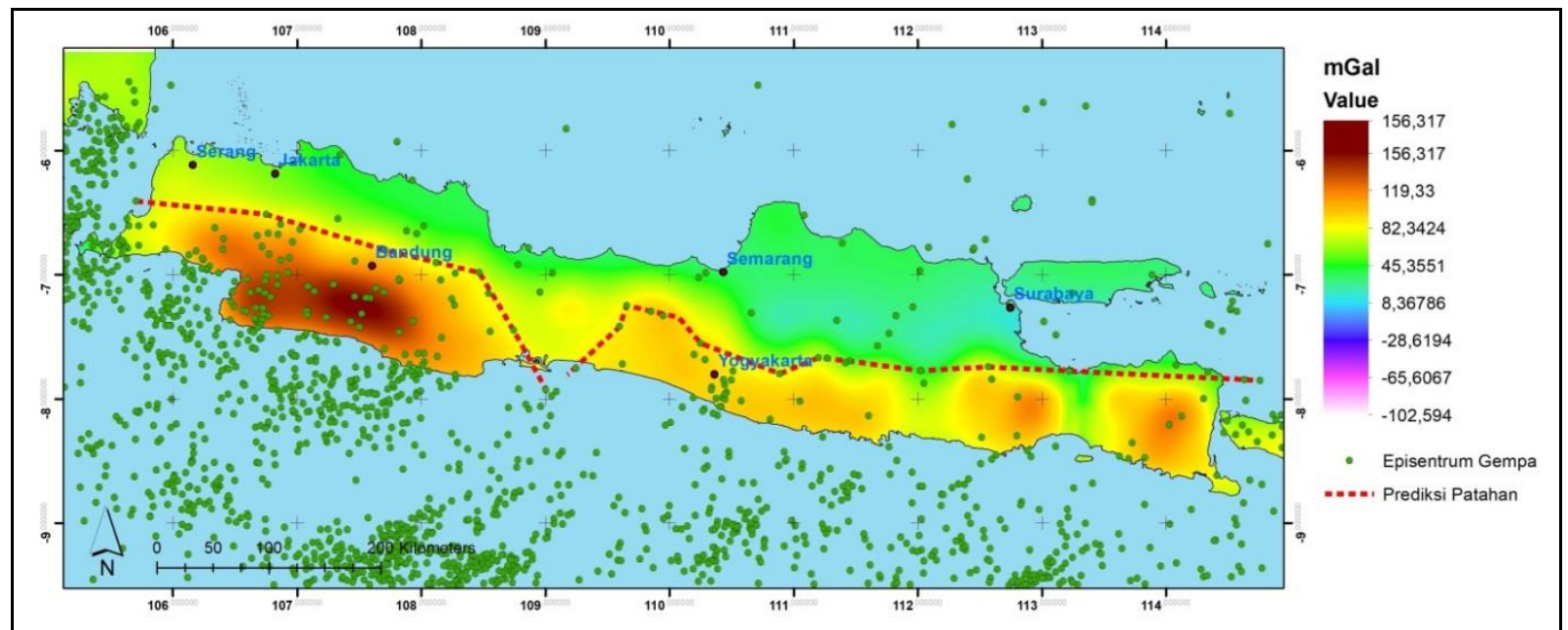

Gambar 7. Analisis pendugaan patahan di anomali gravitasi regional.

Patahan yang cenderung tergambar dengan jelas pada anomali regional adalah patahan yang berpengaruh secara dominan di Pulau Jawa. Berdasarkan data yang ditampilkan, terdapat kemenerusan kontras nilai gravitasi yang melintang relatif timurbarat sepanjang Pulau Jawa dan ditunjukkan pada Gambar 7 dengan garis putus-putus berwarna merah. Sepanjang kemenerusan ini, ditemukan adanya titik-titik episentrum gempa. Dari keterkaitan data yang ada, garis kemenerusan ini dapat diperkirakan sebagai patahan.

Data anomali residual dipetakan dan ditampilkan pada Gambar 8. Nilai anomali residual didapatkan dari pengurangan nilai anomali gravitasi dengan anomali regional. Anomali residual adalah anomali gravitasi yang memiliki pengaruh area sempit atau lokal sehingga patahan yang dapat tergambar pada anomali residual cenderung merupakan patahan yang berpengaruh pada area yang relatif terbatas. Pada anomali residual, dilakukan analisis perkiraan patahan dengan metode yang sama dengan anomali regional.

Perkiraan kemenerusan patahan ditunjukkan dengan garis putus-putus berwarna coklat pada Gambar 8. Garis kemenerusan pada anomali residual cenderung pendek karena sifat anomali residual menonjolkan anomali yang berpengaruh dalam area sempit atau lokal. Pada hasil analisis perkiraan patahan, terdapat satu buah garis kemenerusan yang relatif lebih panjang dari garis kemenerusan lain dan melintang sepanjang pulau dengan arah barattimur. Kemenerusan dapat berupa gabungan dari beberapa kemenerusan anomali residual yang memiliki pola arah yang sama sehingga terlihat menyatu dan memiliki pengaruh yang luas. Kemenerusan anomali residual ini ditarik menjadi satu garis perkiraan patahan dikarenakan kemenerusan tersebut dapat menggambarkan dengan baik hubungan antar titik-titik gempa yang dilewati kemenerusan tersebut meskipun terpisah cukup jauh. Adanya kontras anomali residual pada sepanjang garis kemenerusan ini kemungkinan dipengaruhi oleh satu faktor yang sama.

Hasil gabungan analisis perkiraan kemenerusan patahan dari anomali regional dan residual ditunjukkan pada Gambar 9. Perkiraan patahan ini ditarik berdasarkan kemenerusan kontras nilai anomali gravitasi sehingga jenis patahan-patahan tersebut dipastikan berupa patahan turun atau patahan naik. Pada Gambar 9, masih terdapat titik- 
titik episentrum gempa yang membentuk suatu kemenerusan tetapi tidak terdapat indikasi keberadaan patahan berdasar nilai anomali gravitasi. Titik-titik episentrum yang membentuk kemenerusan ini ditunjukkan dengan garis putus-putus berwarna biru pada Gambar 9. Kemenerusan ini diperkirakan adalah patahan mendatar yang ada di Pulau Jawa. Patahan mendatar tidak menimbulkan perubahan posisi massa batuan secara vertikal sehingga keberadaan patahan mendatar ini tidak dapat dianalisis menggunakan nilai anomali gravitasi.

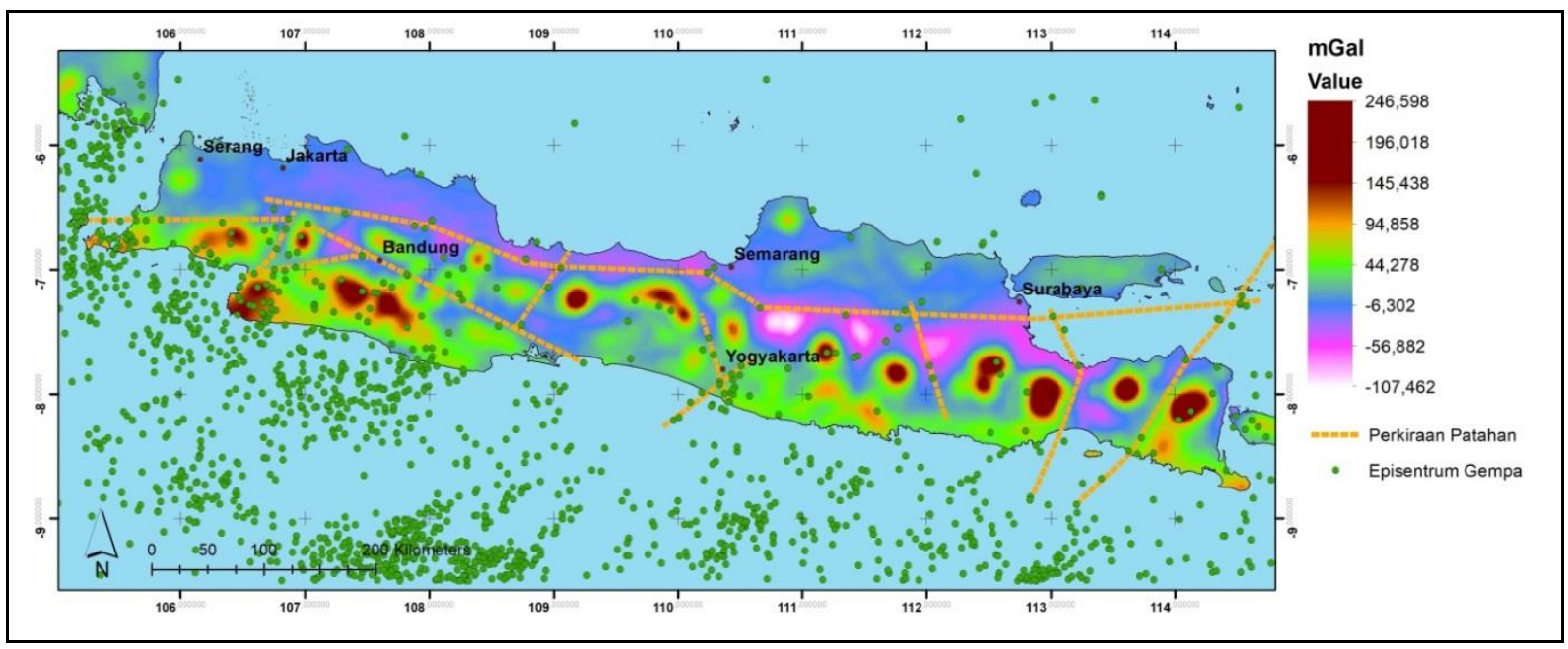

Gambar 8 Analisis pendugaan patahan di anomali gravitasi residual.

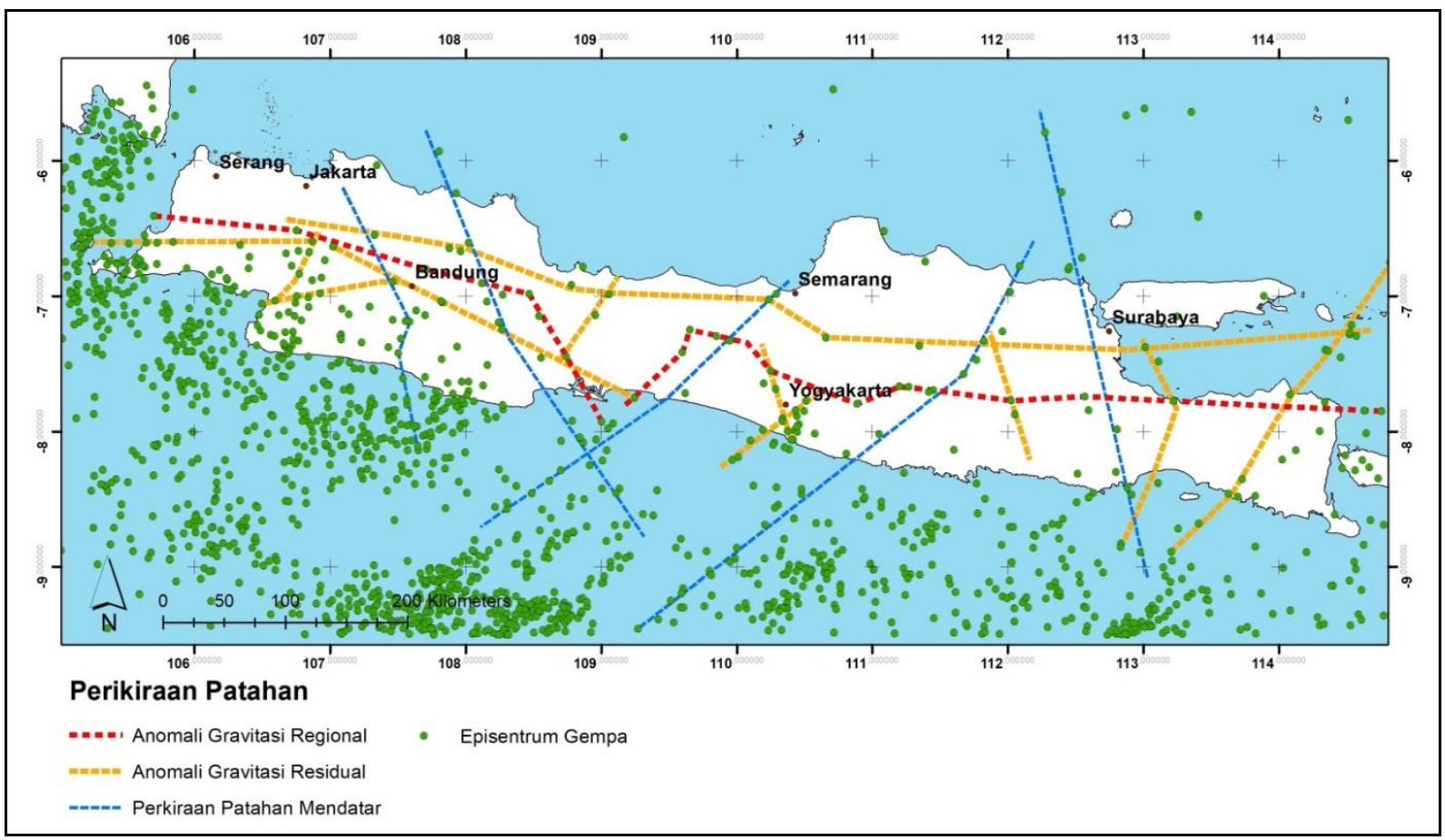

Gambar 9. Hasil analisis perkiraan patahan di pulau Jawa.

Hasil analisis perkiraan patahan yang telah dilakukan pada penelitian ini dibandingkan dengan hasil penelitian tentang patahan aktif yang telah diterbitkan sebelumnya. Hal ini dilakukan untuk melihat tingkat kredibilitas hasil analisis patahan. 
Patahan aktif yang digunakan sebagai pembanding adalah patahan aktif yang diterbitkan oleh PuSGeN [3]. Gambar 10 menunjukkan gabungan data seluruh hasil analisis perkiraan patahan yang telah dilakukan dan data patahan aktif berdasarkan PuSGeN tahun 2017. Patahan aktif dari PuSGeN ditunjukkan dengan garis hitam pada peta.

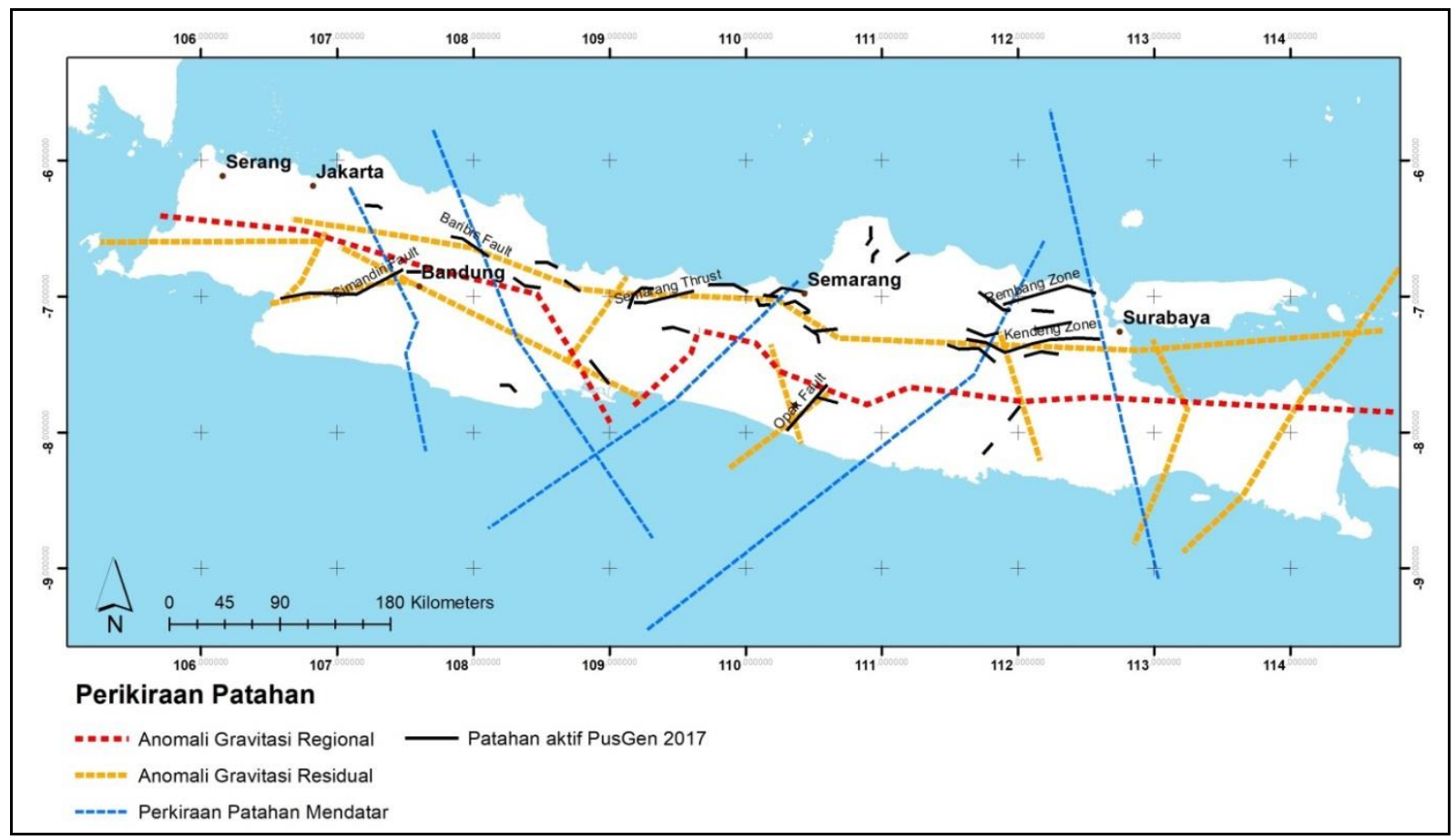

Gambar 10. Perbandingan antara hasil analisis dengan patahan aktif PusGeN.

Secara umum, kombinasi data anomali gravitasi udara bebas dengan data kegempaan dapat digunakan untuk analisis pendugaan awal patahan secara regional dengan hasil yang cukup kredibel. Patahan Cimandiri serta Patahan Lembang yang berada di sebelahnya memiliki posisi dan arah kemenerusan yang relatif sama dengan salah satu perkiraan patahan aktif dari data anomali gravitasi residual (Gambar 10). Selain itu, Patahan Opak juga berhimpit dengan hasil analisis perkiraan patahan aktif dari data anomali gravitasi residual. Hasil analisis perkiraan patahan pada anomali gravitasi residual menunjukkan Patahan Baribis, Patahan Naik Semarang, serta Zona Kendeng yang berada sepanjang utara Pulau Jawa berada dalam satu garis perkiraan patahan yang telah dibahas sebelumnya. Berdasarkan hal tersebut, ketiga patahan ini diperkirakan ditekan oleh faktor gaya yang sama atau dimungkinkan ketiga patahan tersebut merupakan satu patahan besar sepanjang Pulau Jawa bagian utara. Hasil yang sama juga ditunjukkan dari penelitian lain mengenai perkiraan patahan di Pulau Jawa [15].

Pada studi lebih detail, idealnya dilakukan pengolahan lanjutan pada data anomali udara bebas hingga mendapat nilai anomali Bouger agar dapat dianalisis lebih lanjut. Akan tetapi, untuk analisis pendugaan awal data anomali gravitasi udara bebas dapat digunakan dan memberi hasil yang cukup baik.

Berdasarkan hasil perkiraan patahan yang telah dilakukan, terdapat beberapa daerah yang direkomendasikan menjadi tapak PLTN di Pulau Jawa. Daerah timur laut Pulau Jawa 
di sebelah timur Kota Semarang serta bagian barat laut Pulau Jawa di daerah Serang dan sekitarnya cenderung memiliki aktivitas gempa yang minim dan tidak terdapat kontras nilai anomali gravitasi sehingga kemungkinan keberadaan patahan pada daerah tersebut relatif minimal. Daerah tersebut dapat dipilih sebagai lokasi studi detail selanjutnya untuk tapak PLTN bila dibutuhkan.

\section{KESIMPULAN}

Hasil analisis perkiraan patahan yang telah dilakukan di Pulau Jawa menunjukkan bahwa kombinasi antara data anomali gravitasi dan data gempa dapat digunakan untuk memperkirakan keberadaan patahan. Patahan Cimandiri, Patahan Lembang, dan Patahan Opak hasil analisis dari PuSGeN dapat tergambar pada hasil analisis perkiraan patahan yang telah dilakukan. Selain itu, dari analisis yang telah dilakukan, Patahan Baribis, Semarang, dan Zona Kendeng diperkirakan ditekan oleh gaya dengan arah yang sama dan memungkinkan untuk tersambung. Terdapat dua daerah yang belum memperlihatkan adanya patahan menurut data anomali gravitasi dan kegempaan, yaitu daerah timur laut dan barat laut Pulau Jawa.

\section{UCAPAN TERIMA KASIH}

Penulis mengucapkan banyak terima kasih kepada Dr. Suparman selaku Kepala PKSEN, Dr. Sunarko selaku Kepala Bidang Kajian Data Tapak, dan semua pihak terkait yang telah memberi arahan dan masukan sehingga karya tulis ini dapat diselesaikan.

\section{DAFTAR PUSTAKA}

[1] Kementrian ESDM, "Statistik Ketenagalistrikan 2017," Kementrian ESDM Direktorat Jenderal Ketenagalistrikan, 2018.

[2] BAPETEN, Peraturan Kepala BAPETEN No 8 Tahun 2013 tentang Evaluasi Tapak Instalasi
Nuklir Untuk Aspek Kegempaan. Indonesia: Badan Pengawas Tenaga Nuklir (BAPETEN), 2013.

[3] Tim Pusat Studi Gempa Nasional, Peta Sumber dan Bahaya Gempa Indonesia Tahun 2017, 1st ed. Bandung: Kementerian PU dan PERA, 2017.

[4] PKSEN-BATAN, "Laporan evaluasi tapak," Badan Tenaga Nuklir Nasional (BATAN), 2016.

[5] S. A. S. Araffa, F. A. M. Santos, and T. ArafaHamed, "Delineating Active Faults by Using Integrated Geophysical Data at Northeastern Part of Cairo, Egypt," NRIAG J. Astron. Geophys., vol. 1, no. 1, pp. 33-44, 2012.

[6] W. Lowrie, Fundamentals of geophysics, Second Edi., vol. 79, no. 15. New York: Cambridge University Press, 2006.

[7] R. J. Blakely, Potential Theory in Gravity \& Magnetic Applications, vol. 133, no. 2. Cambridge: Cambridge University Press, 1995.

[8] J. Purnomo, S. Koesuma, and M. Yunianto, "Pemisahan Anomali Regional-Residual pada Metode Gravitasi Menggunakan Metode Moving Average, Polynomial dan Inversion," Indones. J. Appl. Phys., vol. 3, no. 1, p. 10, 2016.

[9] K. L. Mickus, C. L. V. Aiken, and W. D. Kennedy, "Regional- residual gravity anomaly separation using the minimum- curvature technique," Geophysics, vol. 56, no. 2, pp. 279283, 1991.

[10] M. I. Nurwidyanto, "Pemodelan Anomali Gravitasi Sesar Dengan Pendekatan Model Sheet ( Modelling Gravity Anomalies of Fault By Sheet Model Approach )," Berk. Fis., vol. 14, no. 3, pp. 129-134, 2011.

[11] D. McGeary, C. C. Plummer, and D. H. Carlson, Physical Geology, Earth Revealed, Fourth Edi. New York: McGraw-Hill, 2001.

[12] N. A. Ferani, E. Hartantyo, and S. W. Niasari, "Spatial Analysis of Gravity Data in the California, Nevada, and Utah (US)," J. Phys. Conf. Ser., vol. 1011, no. 1, pp. 0-5, 2018.

[13] Y. H. Ali, A. L. I. Azimi, and A. Wulandari, "Pemetaan Sesar Nusa Laut Berdasarkan Hiposenter Gempa Bumi Nusa Laut Agustus September 2015 Dan Data Gravitasi," in Proseding Seminar Nasional Fisika dan Aplikasinya, 2015, no. SEPTEMBER, pp. 11-18.

[14] N. O. Mariita, "The gravity method," in Short Course II on Surface Exploration for Geothermal Resources, 2007, p. 9.

[15] A. Koulali, S. McClusky, S. Susilo, Y. Leonard, P. Cummins, P. Tregoning, I. Meilano, J. Efendi, and A. B. Wijanarto, "The kinematics of Crustal Deformation in Java from GPS Observations: Implications for Fault Slip Partitioning," Earth Planet. Sci. Lett., vol. 458, pp. 69-79, 2017. 